\title{
Hubungan Antara Persepsi Kerja Kelompok dengan Hasil Pemecahan Masalah dalam Pembelajaran Biologi Berbasis Masalah Siswa Kelas XI SMAN 6 Kota Bengkulu
}

\author{
Mareta Widiya \\ STKIP-PGRI Lubuklinggau \\ surat elektronik: maretawidiya@gmail.com
}

\begin{abstract}
ABSTRAK
Penelitian ini bertujuan untuk menguji hubungan antara persepsi kerja kelompok dengan hasil pemecahan masalah dalam Pembelajaran Biologi Berbasis Masalah (PBM) siswa kelas XI IPA SMAN 6 Kota Bengkulu. Metode yang digunakan dalam penelitian ini adalah metode korelasi.Subjek penelitian yang digunakan adalah siswa kelas XI IPA SMAN 6 Kota Bengkulu yang berjumlah 35 siswa. Instrumen penelitian yang digunakan adalah angket dan rubrik penilaian. Angket digunakan untuk mengukur persepsi kerja kelompok dalam Pembelajaran Berbasis Masalah (PBM), rubrik penilaian digunakan untuk mengukur hasil pemecahan masalah dalam Pembelajaran Berbasis Masalah (PBM). Teknik analisis data yang digunakan untuk menguji hubungan antara persepsi kerja kelompok dengan hasil pemecahan masalah dalam pembelajaran biologi berbasis masalah (PBM) dihitung dengan menggunakan rumus korelasi Pearson Product Moment. Hasil yang diperoleh dalam penelitian ini yaitu rata-rata skor persepsi kerja kelompok dalam Pembelajaran Berbasis Masalah (PBM) adalah 76,37 sehingga tergolong kedalam kategori cukup. Sedangkan rata-rata skor hasil pemecahan masalah dalam model Pembelajaran Berbasis Masalah (PBM) adalah 245,43 dan tergolong kedalam kategori cukup. Tidak ada hubungan antara persepsi kerja kelompok dengan hasil pemecahan masalah dalam Pembelajaran Berbasis Masalah (PBM) siswa kelas XI IPA SMAN 6 Kota Bengkulu.
\end{abstract}

Kata kunci: Persepsi Kerja Kelompok, Hasil Pemecahan Masalah, Model Pembelajaran Berbasis Masalah (PBM)

\section{Pendahuluan}

Perkembangan dunia di era globalisasi ini memang banyak menuntut perubahan ke sistem pendidikan nasional yang lebih baik serta mampu bersaing secara sehat dalam segala bidang. Dalam peraturan Undangundang Republik Indonesia nomor 20 tahun 2003 tentang Sistem Pendidikan Nasional (Hasbullah, 2009:304), dijelaskan bahwapendidikan adalah usaha sadar dan terencana untuk mewujudkan suasana belajar dan proses pembelajaran agar peserta didik secara aktif mengembangkan potensi dirinya untuk memiliki kekuatan spiritual keagamaan, pengendalian diri, kepribadian, kecerdasan, akhlak mulia, serta keterampilan yang diperlukan dirinya, masyarakat, bangsa dan negara.

Penguasaan kompetensi pemahaman konsep dan kerja ilmiah oleh siswa merupakan target mata pelajaran Biologi di setiap sekolah. Sekolah juga mengharapkan siswanya memperoleh nilai di atas standar ketuntasan, baik untuk kompetensi pemahaman konsep maupun kompetensi kerja ilmiah. Standar ketuntasan minimal untuk kedua kompetensi tersebut untuk mata pelajaran Biologi di SMAN 6 Kota Bengkulu adalah 73.
Kompetensi dalam pembelajaran Biologi tersebut sangat erat kaitannya dengan pembelajaran yang kreatif dan inovatif serta sinergis dengan paradigma baru dalam dunia pendidikan yang berorientasi pada pencapaian kompetensi. Dalam hal ini, tanggung jawab belajar berada pada diri siswa, tetapi guru tetap bertanggung jawab untuk menciptakan situasi yang mendorong prakarsa, motivasi dan tanggung jawab siswa untuk terus belajar. Oleh karena itu peranan guru lebih bertindak sebagai mediator, fasilitator, dan motivator (Amir, 2010:44). Pembelajaran yang dirancang tersebut hendaknya disesuaikan dengan keadaan atau situasi dan kondisi di kehidupan nyata, sehingga pembelajaran menjadi lebih bermakna dan kontekstual, artinya menyentuh langsung dalam kehidupan nyata sehari-hari.

Persoalan sekarang adalah bagaimana menemukan cara yang terbaik untuk menyampaikan berbagai konsep yang diajarkan sehingga siswa dapat menggunakan dan mengingat lebih lama konsep tersebut. Bagaimana guru dapat membuka wawasan berfikir yang beragam dari seluruh siswa, sehingga dapat mempelajari berbagai konsep secara bersama-sama dan mengkaitkannya dalam kehidupan nyata. Bagaimana sebagai guru yang baik dan bijaksana mampu menggunakan model pembelajaran yang inovatif, kreatif dan merangsang siswa untuk 
mengarahkan siswa berfikir memecahkan masalah atau memberikan solusi dari permasalahan nyata (Trianto, 20I I:90).

Salah satu model pembelajaran yang dapat diterapkan untuk siswa mampu memecahkan masalah dan melakukan pertukaran ide-ide yang beragam yaitu model PBM (Pembelajaran berbasis masalah). PBM yaitu suatu model pembelajaran yang menggunakan masalah dunia nyata sebagai suatu konteks bagi siswa untuk belajar melalui berfikir kritis dan keterampilan memecahkan masalah dalam rangka memperoleh pengetahuan dan konsep yang esensi dari materi pembelajaran. PBM mengharuskan guru untuk mengembangkan keterampilan kolaborasi diantara siswa, membantu mereka untuk menginvestigasi masalah secara bersama-sama serta merencanakan tugas investigatif dan pelaporannya dengan presentasi (hasil pemecahan masalah). Hasil pemecahan masalah dalam PBM itu sendiri didapat siswa melalui pertukaran ide-ide saat siswa melakukan kerja kelompok dalam tahap-tahap PBM.

Salah satu aspek penting dalam penggunaan kerja kelompok adalah bahwa selain membantu meningkatkan perilaku kerja kelompok dan hubungan kelompok dengan baik antara siswa, pada saat yang sama juga membantu siswa dalam pembelajaran akademiknya, dengan kelompok belajar secara aktif dan kesempatan untuk mengungkapkan sesuatu yang dipikirkan siswa kepada teman akan membantunya untuk melihat sesuatu dengan lebih jelas bahkan melihat ketidaksesuaian pandangan mereka sendiri (Arends, 2008:12).

Berdasarkan hasil observasi dan wawancara dengan guru Biologi di SMAN 6 Kota Bengkulu, diperoleh informasi bahwa pembelajaran menggunakan model PBM sangat jarang sekali diterapkan, hal ini disebabkan karena umumnya guru terbiasa menggunakan model pembelajaran dengan cara diskusi kelompok yang biasa. Diskusi kelompok yang biasa disini maksudnya adalah dalam mengajar guru tidak memberikan pertanyaan yang mengaitkan materi pembelajaran dengan masalah yang ada dikehidupan sehari-hari dan siswa juga kurang dilibatkan dalam penyelidikan untuk memecahkan suatu masalah. Sehingga menyebabkan siswa merasa jenuh dan merasa tidak tertarik untuk belajar.

\section{Metode Penelitian}

Jenis penelitian yang digunakan dalam penelitian ini yaitu penelitian korelasi (Applied Research). Subjek pada penelitian ini adalah seluruh siswa di kelas XI IPAB SMAN 6 Bengkulu yang berjumlah 35 siswa, yaitu laki-laki 9 orang dan perempuan 26 orang. Variabel dalam penelitian ini adalah persepsi kerja kelompok dalam PBM dan hasil pemecahan masalah dalam PBM.

I.) Persepsi kerja kelompok dalam PBM adalah pemaknaan siswa mengenai kerja kelompok yang dilakukan dalam model PBM, yaitu kerja kelompok saat orientasi masalah, kerja kelompok saat organisasi pebelajar (mengeksplorasi masalah), kerja kelompok saat investigasi, kerja kelompok saat mengembangkan dan mempresentasikan hasil karya, serta kerja kelompok saat menganalisis dan mengevaluasi hasil pemecahan masalah.

2.) Hasil pemecahan masalah dalam PBM adalah pemaparan atau presentasi mengenai informasi hasil penyelidikan, yang dilakukan pada tahap menyajikan hasil karya. Presentasi tersebut dinilai berdasarkan kriteria dalam menilai kualitas presentasi yang baik yaitu masalah autentik, isi pemecahan masalah, ketepatan menjawab dan tampilan power point.

Instrumen yang digunakan dalam penelitian ini adalah angket persepsi kerja kelompok dalam PBM dan rubrik penilaian hasil pemecahan masalah dalam PBM.

I. Angket persepsi kerja kelompok dalam model PBM

Angket digunakan untuk mengumpulkan data persepsi kerja kelompok dalam PBM. Bentuk angket yang digunakan adalah angket tertutup. Angket digunakan untuk mengumpulkan data persepsi kerja kelompok dalam PBM. Bentuk angket yang digunakan adalah angket tertutup. Tingkatan respon angket yang digunakan adalah sangat setuju (SS), setuju (S), tidak setuju (TS), dan sangat tidak setuju (STS). Prosedur dalam mengembangkan instrumen angket dalam penelitian ini yaitu menentukan variabel yang akan digunakan yaitu persepsi kerja kelompok dalam model PBM, sub-variabel dan indikator dianalisis berdasarkan kerja kelompok yang dilakukan dalam model PBM, lalu dibuat butir pernyataan terkait kajian teori (manfaat kerja kelompok dalam model PBM). Jumlah butir angket sebelum divalidasi yaitu sebanyak 28 butir dan setelah divalidasi menjadi 23 butir.

2. Rubrik Penilaian presentasi hasil karya

Rubrik penilaian adalah pedoman atau seperangkat kriteria penskoran yang digunakan untuk mengevaluasi kinerja atau unjuk kerja peserta didik (Tianto, 201 I:259). Rubrik penilaian digunakan untuk menilai presentasi hasil karya siswa dalam model PBM. Ada dua jenis rubrik, yaitu holistik dan analitik. Rubrik yang digunakan dalam penelitian ini adalah rubrik analitik. Rubrik analitik digunakan untuk menilai hasil pemecahan masalah dalam bentuk presentasi hasil karya. Rubrik penilaian disusun berdasarkan kriteria menilai kualitas presentasi yaitu: Masalah, hasil pemecahan masalah, ketepatan menjawab pertanyaan, tampilan power point.

Adapun tahapan pengembangan rubrik penilaian pada penelitian ini adalah sebagai berikut: I) menentukan variabel dan sub-variabel yang diteliti. Variabelnya yaitu persepsi kerja kelompok dan hasil pemecahan masalah dalam model PBM. Sub-variabel pada penelitian ini yaitu sesuai dengan kinerja yang dinilai berupa kualitas presentasi penyajian hasil karya. 2) menentukan indikator dari subvariabel, yaitu disusun berdasarkan kriteria syarat menilai kualitas presentasi yang baik yaitu: Masalah, isi hasil pemecahan masalah, 
ketepatan menjawab pertanyaan, tampilan power point (Iryanti, 2004:17 dan Arends, 2008:66); 3) menentukan skala nilai yang digunakan. Pada penelitian ini skala nilai yang digunakan adalah I-3; 4) Mendeskripsikan kinerja mulai dari yang diharapkan sampai dengan kinerja yang tidak diharapkan; 5) melakukan uji validitas logis, dimana uji validitas logis dalam hal ini yaitu dosen pembimbing peneliti; 6) merevisi rubrik penilaian

Prosedur dalam penelitian ini mempunyai 4 tahap yaitu tahap persiapan penyusunan instrumen, tahap penggandaan instrumen, tahap perencanaan pengumpulan data dan tahap pengumpulan data.

a. Tahap persiapan penyusunan instrument: I) Menentukan variabel yang hendak diukur, yaitu variabel persepsi kerja kelompok dalam PBM dan hasil pemecahan masalah dalam PBM; 2) Membuat subvariabel dan indikator yang dianalisis berdasarkan kajian teori terkait kerja kelompok yang dilakukan dalam setiap tahap PBM serta manfaatnya dan hasil pemecahan masalah dianalisis terkait dengan cara menilai pemecahan masalah yang baik. 3) Membuat kisi-kisi instrumen yang dikembangkan dari indikator. 4) Memvalidasi instrumen yang dilakukan oleh para ahli.

b. Tahap penggandaan instrument: Mempersiapkan angket yang sudah disusun dan difoto copy sesuai dengan jumlah responden yang diteliti, yaitu berjumlah 34 siswa. Untuk rubrik penilaian difoto copy sesuai dengan banyaknya kelompok yang dinilai.

c. Tahap mengumpulkan data: I) Pengisian angket dan rubrik dilakukan di SMAN 6 Kota Bengkulu pada tanggal I5 Januari 2013 di ruangan kelas XI IPAв 2) Menjelaskan tujuan penyebaran angket dan petunjuk pengisian angket; 3) Memberikan waktu kepada siswa untuk mengisi angket kisaran 20 menit 4) Memeriksa kelengkapan pengisian angket, angket yang tidak lengkap pengisiannya dikembalikan kembali kepada siswa untuk dilengkapi. 5) Untuk data hasil pemecahan masalah dalam PBM diperoleh dengan cara observasi langsung dengan membandingkan hasil presentasi masing-masing kelompok siswa sesuai dengan kriteria penilaian pada rubrik, lalu memberikan tanda centang pada kolom kategori pada rubrik yang telah disediakan. 6) Respon siswa pada angket diolah dengan mengkuantitatifkan atau mengangkakannya.

\section{Teknik Analisis Data}

Teknik analisis data untuk menguji hubungan antara persepsi kerja kelompok dengan hasil pemecahan masalah dalam PBM pada siswa kelas XI IPAB SMAN 6 Kota Bengkulu yaitu dengan menggunakan rumus korelasi Pearson Product Moment (Arikunto, 2010:318).

$$
r_{x y}=\frac{n \sum X Y-\left(\sum X\right)\left(\sum Y\right)}{\sqrt{\left\{n \sum X^{2}-\left(\sum X\right)^{2}-\right\}\left\{n \sum Y^{2}-\left(\sum Y\right)^{2}\right\}}}
$$

Keterangan:

$\mathrm{R}_{\mathrm{xy}}$ : Koefisien korelasi Pearson Product Moment PBM

$\mathrm{X}$ : Skor dari variabel persepsi kerja kelompok dalam

Y : Skor dari variabel hasil pemecahan masalah dalam PBM

$\mathrm{N}$ : Jumlah subyek
$\mathrm{Uji}_{\mathrm{ji}}$ hipotesis hubungan antara persepsi tentang kerja kelompok dengan hasil pemecahan masalah dalam model PBM adalah dengan membandingkan rhitung dengan rabel pada taraf signifikan $5 \%$. Hipotesis yang diajukan dapat diterima dan ditolak dengan ketentuan menurut Arikunto (2010:214) sebagai berikut :

a. Hipotesis riset $(\mathrm{Ha})$ diterima jika rhitung $>$ rabel

b. Hipotesis riset $(\mathrm{Ha})$ ditolak jika rhitung $<$ rabel

Sebelum dikorelasikan, data persepsi kerja kelompok dalam model PBM dianalisis secara deskriptif dengan Ratarata, Standar Deviasi dan Persentase. Rata-rata digunakan untuk memperoleh gambaran rerata skor persepsi tentang kerja kelompok dalam model PBM dihitung dengan menggunakan rumus dalam (Arikunto, 2010:315)

$$
\begin{aligned}
& \text { a. Rerata } \\
& X=\frac{\sum X}{N} \\
& \text { Keterangan: } \\
& X=\text { Rata-rata skor angket } \\
& \mathrm{N}=\text { Banyaknya Subyek penelitian } \\
& \Sigma X=\text { Jumlah skor angket }
\end{aligned}
$$

\section{b. Standar Deviasi}

Standar deviasi skor persepsi kerja kelompok dalam model PBM dihitung dengan menggunakan rumus dalam (Riduwan, 2003:146)

$$
S D=\sqrt{\frac{\sum X^{2} \frac{\left(\sum X\right)^{2}}{N}}{N-1}}
$$

Keterangan :

$\mathrm{SD}=$ Standar Deviasi

$X \quad$ total skor

$X^{2} \quad=$ total skor dikuadratkan

$\mathrm{N}=$ Jumlah subyek

c. Persentase siswa untuk tiap kategori

Persentase digunakan untuk memperoleh gambaran jumlah persentase dari siswa untuk setiap kategori persepsi kerja kelompok dalam model PBM dengan menggunakan rumus:

$$
\text { persentase siswa kategori } \mathrm{X}=\frac{\text { Jumlah siswa untuk kategori } \mathrm{X}}{\text { Jumlah seluruh siswa }} \mathrm{X} 100 \%
$$

d. Rentang setiap kategori

Kategori skor aspek persepsi kerja kelompok dalam model PBM dan skor hasil pemecahan masalah dalam model PBM ditentukan dengan menghitung rentang setiap kategori menurut Arifin, ( 2010:24I), sebagai berikut:

Rentang tiap aspek $=\frac{\text { skor maksimum }- \text { skor minimum }}{\text { Jumlah kategori }}$

Sebelum dikorelasikan, skor data hasil pemecahan masalah dihitung dengan menggunakan rumus menurut Bathesta dan Wahyuni (2011:21) :

$$
\text { penilaian }=\frac{\text { skor yang didapat }}{\text { skor maksimal }}
$$

Respon siswa pada angket diolah dengan mengkuantitatifkan atau mengangkakannya. Respon terhadap pernyataan positif diberi skor 4 sangat setuju (SS), 3 setuju (S), 2 tidak setuju (TS), I sangat tidak setuju (STS). Respon terhadap pernyataan negatif diberi 
skor kebalikannya yaitu respon I sangat setuju (SS), 2 setuju (S), 3 tidak setuju (TS), 4 sangat tidak setuju (STS).Sedangkan kategori untuk menskor hasil pemecahan masalah pada penelitian ini yaitu ada3kategoriyaitu:baik (3), cukup (2), kurang (I).

Metode penelitian pada dasarnya merupakan langkah-langkah atau prosedur yang dilakukan dalam pengumpulan, pengolahan dan analisis data untuk mendeskripsi pemecahan masalah dari penelitian dan menguji hipotesis.

\section{Hasil dan Pembahasan}

Persepsi kerja kelompok dalam model pembelajaran berbasis masalah

Rata-rata skor persepsi siswa mengenai kerja kelompok dalam model pembelajaran berbasis masalah adalah 76,37 dengan standar deviasi sebesar 7,68. Ratarata skor persepsi mengenai kerja kelompok dalam model pembelajaran berbasis masalah tersebut tergolong ke dalam kategori baik karena berada pada kisaran 65 - 78 . Skor tertinggi yang diperoleh siswa yaitu 90 dari skor maksimum 92 dan skor terendah yang diperoleh siswa adalah 60 dari skor minimum adalah 23 .

Kategori persepsi tiap individu siswa terhadap kerja kelompok dalam pembelajaran berbasis masalah dari 35 siswa yaitu, $0 \%$ siswa tergolong sangat kurang dan kurang, 5,71\% tergolong cukup, 51,43\% tergolong baik dan $42,86 \%$ tergolong sangat baik (Gambar I).

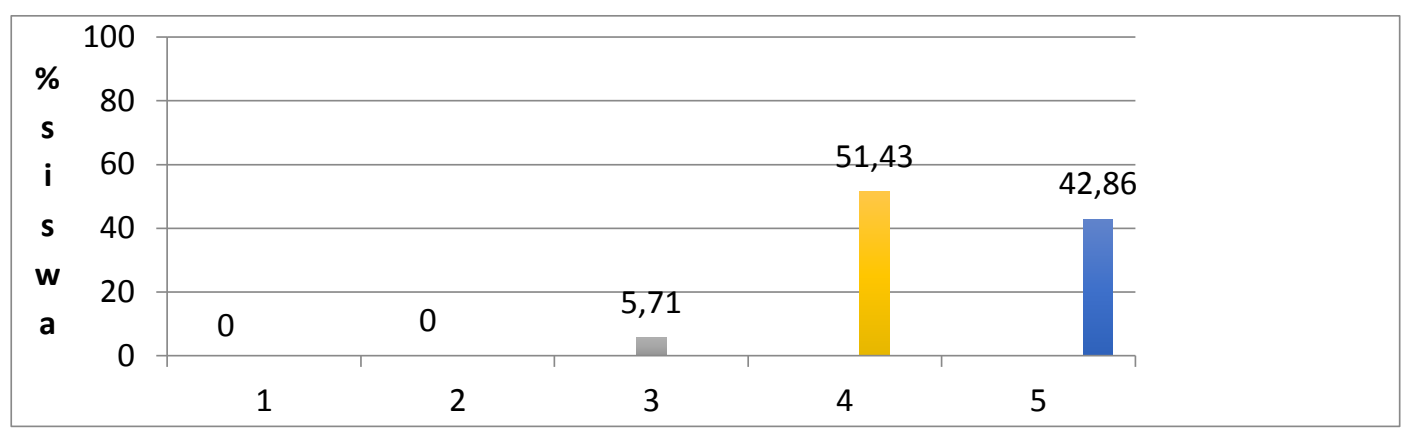

Gambar I. Persentase kategori persepsi individu siswa terhadap kerja kelompok dalam model pembelajaran berbasis masalah (PBM).

Analisis aspek persepsi kerja kelompok dalam model PBM, untuk aspek tertinggi diperoleh pada aspek persepsi kerja kelompok saat analisis dan evaluasi proses pemecahan masalah dengan rata-rata 3,44 atau tergolong sangat baik, sedangkan untuk rata-rata aspek yang terendah yaitu persepsi kerja kelompok saat mengembangkan dan menyajikan hasil karya dengan ratarata 3, I9 atau tergolong baik. (Gambar 2)

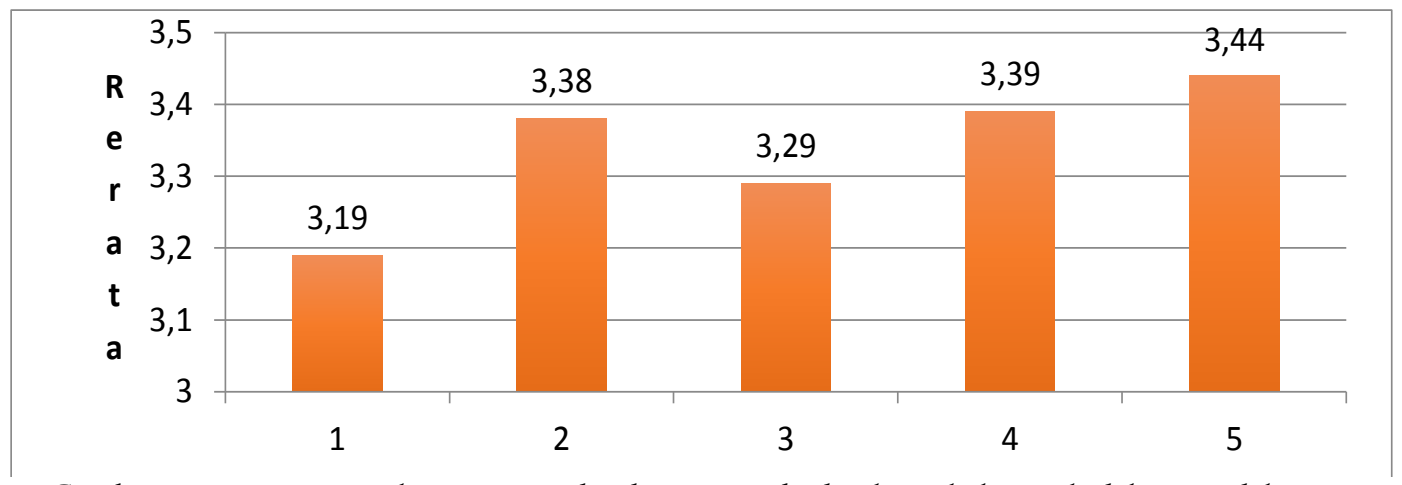

Gambar 2. Rata-rata aspek persepsi individu siswa terhadap kerja kelompok dalam model PBM

Keterangan : I) Aspek persepsi kerja kelompok saat orientasi masalah; 2) Aspek persepsi kerja kelompok saat organisasi pebelajar (mengeksplorasi masalah); 3) Aspek persepsi kerja kelompok saat penyelidikan; 4) Aspek persepsi kerja kelompok saat mengembangkan dan menyajikan hasil karya; 5) aspek persepsi kerja kelompok saat analisis dan evaluasi proses pemecahan masalah.

\section{Hasil Pemecahan Masalah dalam Model Pembelajaran Berbasis Masalah}

Rata-rata hasil pemecahan masalah kelompok siswa di kelas XI IPAB SMA Negeri 6 Kota Bengkulu dalam model pembelajaran berbasis masalah pada pokok bahasan Sistem Pencernaan pada manusia adalah 245,43 dengan standar deviasi 28,2I. Skor rata-rata hasil pemecahan masalah masing-masing kelompok siswa 
tergolong ke dalam kategori baik karena berada pada kisaran skor 220 - 259. Kelompok yang memperoleh skor tertinggi adalah 300 dari skor maksimum 300 , sedangkan kelompok yang memiliki skor terendah adalah 220 dari skor minimum I00. Berdasarkan kategori hasil pemecahan masalah kelompok siswa, kelompok yang tergolong sangat baik 2 kelompok (33,33\%), kategori baik 4 kelompok $(66,67 \%)$ dan kelompok yang tergolong kategori cukup, kurang dan sangat kurang tidak ada (Gambar 3).

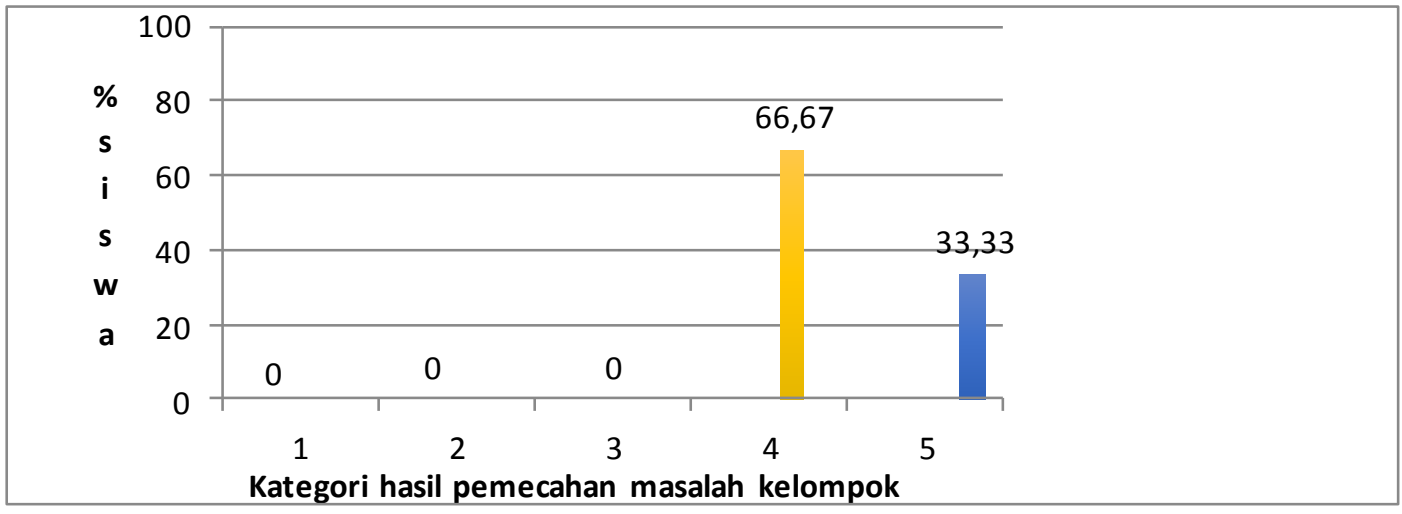

Gambar 3. Persentase kategori hasil pemecahan masalah kelompok siswa dalam model PBM

Untuk rata-rata dan kategori aspek hasil pemecahan masalah pada pokok bahasan Sistem Pencernaan pada Manusia untuk 5 butir kriteria rubrik yaitu keautentikan dan alasan pemilihan masalah $(60,00)$, isi pemecahan masalah $(86,86)$, kejelasan tulisan pada power point
$(46,29)$, kesesuaian dan kemenarikan gambar $(25,43)$, dan untuk jawaban diskusi kelompok $(23,43)$ (Tabel. 2). Tabel 2. Rerata dan kategori aspek hasil pemecahan masalah dalam model PBM pada seluruh kelompok siswa.

\section{Aspek hasil pemecahan masalah $\quad$ Rerata $\begin{gathered}\text { Skor } \\ \text { maksimum }\end{gathered} \quad \begin{gathered}\text { Skor } \\ \text { minimum }\end{gathered} \quad$ Kategori}

\begin{tabular}{lcccc}
\hline Keautentikan masalah & 60 & 60 & 20 & Sangat baik \\
Isi pemecahan masalah & 86,86 & I20 & 40 & Cukup \\
Kejelasan tulisan pada power point & 46,29 & 30 & 10 & Baik \\
Kesesuaian dan kemenarikan gambar & 25,43 & 30 & 10 & Baik \\
Jawaban diskusi kelompok & 23,43 & 60 & 20 & Baik \\
\hline
\end{tabular}

Pada aspek hasil pemecahan masalah, kelompok hasil pemecahan masalahnya paling rendah yaitu yang mendapatkan kategori skor tertinggi yaitu kelompok I yang membahas masalah mengenai penyakit 'Amandel', semua aspek yang dinilai pada kelompok ini tergolong sangat baik, sedangkan kelompok yang aspek

kelompok 2 yang membahas mengenai 'Flatus'.

Berikut ini grafik kategori aspek hasil pemecahan masalah dalam model PBM yang didapat dari masingmasing kelompok siswa (Gambar 4).

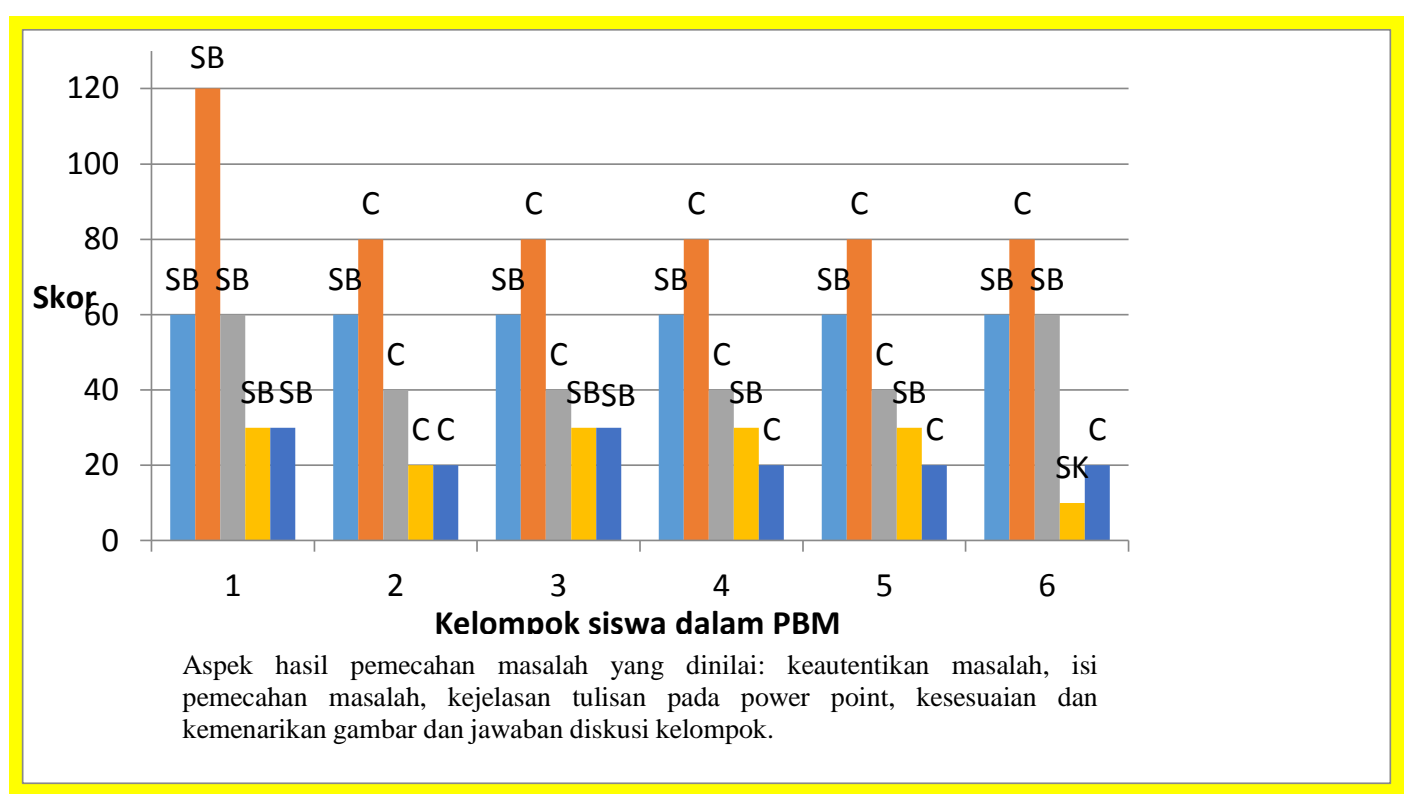

Gambar 4. Skor aspek hasil pemecahan masalah pada kelompok siswa dalam PBM 
Masalah yang diajukan oleh masing-masing kelompok siswa terkait konsep sistem pencernaan yaitu kelompok Imemilih masalah tentang "Amandel", kelompok 2 yaitu "Flatus", kelompok 3 yaitu "Obesitas”, kelompok 4 yaitu "Diare”, kelompok 5 yaitu "Gizi Buruk", sedangkan kelompok 6 yaitu "Usus Buntu”. Hasil inti pemecahan tersebut dapat dilihat pada tabel berikut ini :

Hubungan antara persepsi kerja kelompok dengan hasil pemecahan masalah dalam model pembelajaran berbasis masalah

Berdasarkan analisa korelasi Pearson Product Moment antara persepsi kerja kelompok dalam model pembelajaran berbasis masalah diperoleh koefisien korelasi (rhitung) sebesar -0,037, sedangkan rtabel pada taraf signifikan 5\% dengan jumlah subyek (N) 35 adalah 0,334. Artinya rhitung lebih kecil dari rtabel berarti HO yaitu persepsi kerja kelompok dalam model pembelajaran berbasis masalah tidak berhubungan dengan hasil pemecahan masalah dalam model pembelajaran berbasis masalah diterima, yang juga berarti $\mathrm{Ha}$ yaitu persepsi kerja kelompok dalam model pembelajaran berbasis masalah berhubungan dengan hasil pemecahan masalah dalam model pembelajaran berbasis masalah ditolak. (Gambar 5).

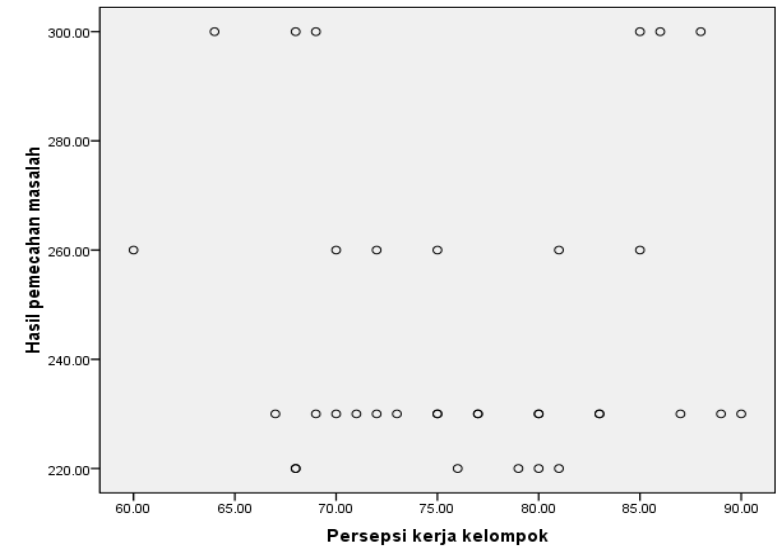

Gambar 5. Hubungan persepsi kerja kelompok dengan hasil pemecahan masalah dalam model pembelajaran berbasis masalah.

Berdasarkan hasil uji korelasi antara persepsi siswa tentang kerja kelompok dengan hasil pemecahan masalah dalam model pembelajaran berbasis masalah, menunjukkan bahwa hipotesis yang diajukan yaitu terdapat korelasi antara persepsi kerja kelompok dengan hasil pemecahan masalah dalam model pembelajaran berbasis masalah siswa di kelas XI IPAB SMA Negeri 6 Kota Bengkulu pada pokok bahasan Sistem Pencernaan pada Manusia ditolak. Hasil penelitian ini mendukung pendapat Huda (2011:19) yang mengatakan bahwa siswa yang belajar secara kelompok tidak lantas berpengaruh signifikan terhadap prestasi belajar mereka, tergantung bagaimana proses dan cara kerja yang mereka alami saat menyelesaikan tugas tersebut. Hal ini juga sesuai dengan data hasil penelitian, diketahui bahwa persepsi siswa tentang kerja kelompok tidak berhubungan dengan hasil pemecahan masalah, karena tidak semua siswa yang memiliki persepsi kerja kelompok baik dan hasil pemecahan masalahnya juga tergolong baik (setara). Ada siswa yang persepsinya cukup tetapi saat bekerja kelompok memecahkan masalahnya baik, seperti pada hasil kerja kelompok I dan kelompok 3.

Hal ini dapat terjadi karena setiap persepsi siswa yang satu dengan yang lainnya mengenai kerja kelompok pada setiap aspek model pembelajaran berbasis masalah itu berbeda tergantung apa yang mereka rasakan saat bekerja kelompok dalam tahap-tahap pembelajaran berbasis masalah bersama teman-temannya, ada siswa yang merasa malas melakukan kerja kelompok pada saat itu dan ada siswa yang merasa sangat menikmati atau menyukai kerja kelompok pada aspek tersebut. Pernyataan ini didukung oleh pendapat Eggendan Kauchack (2012:62-63) yang mengatakan bahwa persepsi setiap individu dibangun karena pengalaman antar siswa berbeda, persepsi mereka mengenai kerja kelompok yang mereka alami bersama akan berbeda. Ada siswa yang akan terfokus pada satu aspek dari suatu kegiatan. Siswa lainnya mungkin terfokus pada aspek yang berbeda lagi. Hal ini menyebabkan mereka menafsirkan informasi mengenai kerja kelompok dalam pembelajaran berbasis masalah itu secara berbeda.

Pada saat bekerja kelompok memecahkan masalah kebanyakan diantara mereka mengeluh dan merasa jenuh dengan belajar secara berkelompok dan lebih menyukai belajar secara mandiri. Faktor inibisa juga disebabkan ketidakseriusan mereka belajar dikarenakan waktu untuk mereka melakukan penyelidikan pemecahan masalah tersebut lebih banyak dilakukan diluar jam sekolah sehingga lebih banyak waktu untuk bermain dibandingkan waktu mereka belajar memecahkan masalah. Halini didukung oleh pendapat Trianto (20II:7) yang mengatakan bahwa ada siswa yang ingin belajar atau berusaha sendiri untuk memecahkan suatu masalah berdasarkan pengetahuan yang dimilikinya sehingga merasa lebih bermakna dibandingkan memecahkan masalah secara berkelompok. Suatu konsekuensi logis, karena dengan berusaha untuk mencari pemecahan masalah secara mandiri akan memberikan suatu pengalaman konkret, dengan pengalaman konkret tersebut siswa dapat memecahkan masalah-masalah yang serupa karena pengalaman itu memberikan makna tersendiri bagi peserta didik.

Menurut Syah (2012:I46-I49), mengatakan bahwa faktor-faktor yang mempengaruhi belajar itu ada 2 yaitu: I.) faktor internal siswa;2.) faktor eksternal siswa. Faktor internal ini seperti pada aspek fisologis siswa, kondisi jasmani yang sehat bisa mempengaruhi semangat dan intensitas siswa dalam mengikuti pelajaran, sedangkan kondisi organ tubuh yang lemah, seperti lemah atau lesu, apalagi jika disertai pusing kepala berat misalnya, dapat menurunkan kualitas siswa dalam belajar (kurang). Selanjutnya yaitu faktor eksternal siswa seperti lingkungan belajar dan waktu untuk belajar, menurut Biggers (I980) dalam Syah (2012:I55) berpendapat 
bahwa belajar pada pagi hari lebih efektif daripada belajar pada waktu-waktu lainnya. Slameto (2010:54), juga menambahkan bahwa proses belajar seseorang akan terganggu jika kesehatan seseorang terganggu, selain itu ia akan cepat lelah, kurang bersemangat, mudah pusing, ngantuk jika badannya lemah. Kemudian, faktor sekolah seperti lingkungan kelas yang berupa relasi siswa dengan siswa juga mempengaruhi siswa dalam belajar.

Dalam model pembelajaran berbasis masalah siswa dituntut untuk belajar secara berkelompok dalam memecahkan suatu masalah terkait kehidupan sehari-hari. Model pembelajaran berbasis masalah ini tidak rumit, akan tetapi pelaksanaan efektif model ini lebih sulit. Model ini membutuhkan banyak latihan dan mengharuskan untuk mengambil keputusan tertentu selama perencanaan dan pelaksaannya. Jadi, guru yang akan menggunakan model ini harus mempunyai kemampuan untuk menghadapi siswa dengan masalahmasalah yang realistis yang akan membantu mereka mengembangkan keterampilan pemecahan masalah (Arends, 2008:49). Ketika kita melakukan penilaian dalam model pembelajaran berbasis masalah banyak kegiatan yang akan lebih jelas apabila dinilai secara langsung, umpamanya kemampuan berargumentasi ataupun berdebat siswa saat melaksanakan presentasi hasil karya kerja kelompok. Inilah yang dikatakan sebagai penilaian berdasarkan pada performa siswa. Siswa diminta untuk mendemonstrasikan pengetahuan dan keterampilan mereka atau kemampuan dalam situasi apapun yang sesuai dengan yang mereka hadapi (Rustaman, 2006:2).

Dari beberapa hasil penelitian juga membuktikan bahwa penggunaan kerja kelompok dapat meningkatkan prestasi belajar siswa sekaligus dapat meningkatkan kemampuan hubungan sosial, menumbuhkan sikap menerima kekurangan diri dan orang lain, dapat merealisasikan kebutuhan siswa dalam berfikir, mengintegrasikan pengetahuan dengan keterampilan, serta salah satu faktor pentingnya yaitu siswa mampu memecahkan masalah sesuai dengan tujuan yang ingin dicapai dalam pembelajaran, Slavin 1995 (Sanjaya, 2006:240).

\section{Simpulan}

I. Persepsi kerja kelompok dalam model pembelajaran berbasis masalah kelas XI IPAB SMAN 6 Kota Bengkulu secara umum tergolong cukup. Rata-rata skor persepsi siswa mengenai kerja kelompok dalam model pembelajaran berbasis masalah adalah 76,37 dengan standar deviasi sebesar 7,68. Berdasarkan kategori Persepsi kerja kelompok dalam model pembelajaran berbasis masalah, dari (N) 35 siswa, 0\% siswa tergolong kategori sangat kurang, $0 \%$ tergolong kategori kurang, 5,7I\% tergolong kategori cukup, $5 \mathrm{I}, 43 \%$ tergolong kategori baik dan 42,86\% tergolong kategori sangat baik.
2. Hasil pemecahan masalah dalam model pembelajaran berbasis masalah siswa kelas XI IPAB SMAN 6 Kota Bengkulu secara umum tergolong cukup. Rata-rata skor hasil pemecahan masalah adalah 245,43 dengan standar deviasi 28,2I. Berdasarkan kategori hasil pemecahan masalah siswa secara kelompok, siswa yang tergolong sangat baik 2 kelompok (33,33\%), kategori baik I kelompok (I6,67\%), kategori cukup, kurang dan sangat kurang tidak ada (0\%).

3. Persepsi kerja kelompok dalam model pembelajaran berbasis masalah tidak berhubungan dengan hasil pemecahan masalah dalam model pembelajaran berbasis masalah di kelas XI IPAB SMAN 6 Kota Bengkulu.

Berdasarkan hasil penelitian yang telah dilakukan maka disarankan:

I. Bagi guru diharapkan dapat mempersiapkan perencanaan pembelajaran menggunakan Model Pembelajaran Berbasis Masalah (PBM) secara matang sehingga saat pelaksanaannya bisa menghadapi siswa dengan masalah-masalah yang realistis yang akan membantu mereka mengembangkan keterampilan pemecahan masalah.

2. Bagi peneliti lanjutan hendaknya dapat melakukan penelitian tentang hubungan antara persepsi kerja kelompok yang dalam pemilihan anggota kelompoknya ditentukan oleh relasi siswa sendiri lalu dihubungkan dengan hasil pemecahan masalah dalam model Pembelajaran Berbasis Masalah (PBM).

\section{Daftar Pustaka}

Amir, M.T. 2010. Inovasi Pendidikan melalui Problem Based Learning: Bagaimana Pendidik memberdayakan Pembelajar di Era Pengetahuan. Jakarta : Prenada Media Grup (hal.44)

Arends, R. I. 2008. Learning to Teach: Belajar untuk Mengajar. Yogyakarta: Pustaka Pelajar (hal. I2, 4I, 49, 56-60, 62 dan 66)

Arikunto, S. (2010). Prosedur Penelitian: Suatu Pendekatan Praktik (edisi revisi). Jakarta: Rineka Cipta (hal. I59, 2I4, 3I5, dan 318)

Bathesta, Y.L.D dan Wahyuni. 20I I. Rubrik: Asesmen Alternatif untuk Menilai Peserta Didik Secara Real Time dan Komprehensif. [Online]. Diakses I8.00 PM, 29/05/2012 di http://images.lussysf.multiply.multiply content.com. (hal. I3, I7 dan 2I)

Eggen, P. D dan Kauchack. 2012. Strategi dan Model Pembelajaran : mengajarkan konten dan keterampilan berfikir. Jakarta : Indeks (hal. 62-63, I63, 345, dan 35I)

Hasbullah. 2009. Dasar-dasar Ilmu Pendidikan. Jakarta : Rajawali Pers (hal. 302 dan 356)

Huda, M. 201 I. Cooperative Learning. Yogyakarta: Pustaka Pelajar (hal.19 dan 32) 
Iryanti, Puji. 2004. Penilaian Unjuk Kerja. Diakses tanggal 29 Oktober 2012 di

p4tkmatematika.org/downloads/PPP/PPPO4_UnjukKe rja.pdf (hal.I7)

Riduwan, 2003. Dasar-dasar Statistika. Bandung : Alfhabeta (hal.146)

Rusman. 20I I. Model-model Pembelajaran Mengembangkan Profesionalisme Guru. Jakarta : Rajawali Pers (hal. 53 dan 242)

Rustaman. Penilaian Otentik dan Penerapannya dalam Pendidikan Sains. Diakses I3.I5 AM, I7/06/2012 di Http://File.Upi.Edu/Direktori/Sps/Prodi.Pendidikan _Ipa/I950123I1979032Nuryani_Rustaman/Penilaian _Otentik_Sgr'06.Pdf (hal.I-2)

Slameto. 20I0. Belajar dan Faktor-Faktor yang Mempengaruhinya. Jakarta: Rineka Cipta (hal.54, I02 dan I43)

Syah. 2012. Psikologi Belajar. Jakarta : Rajawali Pers (hal. I46-I59, I50, dan I55)

Trianto. 20I I. Mendesain Model Pembelajaran Inovatif Progresif. Jakarta: Kencana (hal.7, 59, 90 dan 259) 